\title{
Critical leadership factors to enhance workers performance in the South African construction industry
}

\author{
Emere, $\mathrm{CE}^{1}$, Aigbavboa, $\mathrm{CO}^{2}$, Thwala, $\mathrm{WD}^{3}$ \\ Department of Construction Management \& Quantity Surveying, University of Johannesburg, Johannesburg, 2000, South Africa
}

\begin{abstract}
Leadership is known to be linked with construction workers' performance. Literature suggests that construction workers' morale and engagement are boosted by effective leadership. For South African construction industry to play its part effectively in the Gross Domestic Product (GDP) of South Africa, increase in productivity is vital. Hence, to achieve this goal we cannot negate the need for quality leadership among our project leaders and construction professionals. The main objective of this paper is to investigate the critical leadership factors essential for the enhancement of construction workers' performance for effective project delivery in the South African construction industry. The primary research data were collected through the use of a structure questionnaire survey targeted at 81 construction professionals in the Gauteng Province of South Africa. Respondents were selected using purposive sampling technique. Data from the questionnaire were analysed using Statistical Package for the Social Sciences (SPSS) version 22.0 software. Mean values and standard deviation were computed. The ranks of the critical leadership factors to improve workers' performance were established. Findings from the study revealed that effective communication within the project environment and proper planning of work for the workforce are of the optimum importance for performance enhancement and effectiveness. The study also revealed that the enlistment of subordinates in a common vision by appealing to shared aspirations contributes to optimum performance. It further revealed that good dispute management, continual search for innovative ways of improvement, setting exemplary actions by the leader, proper supervision of work, regular meeting with subordinates, and contingent rewards for job well done are all essential for organisational effectiveness and performance enhancement. The study contributes to the body of knowledge on the effects of effective leadership on project delivery and in turn project success in the South African construction industry.
\end{abstract}

(C) 2018 The Authors. Published by Diamond Congress Ltd., Budapest University of Technology and Economics Peer-review under responsibility of the scientific committee of the Creative Construction Conference 2018.

Keywords: Construction industry; leadership, organisational success.

\section{Introduction}

The construction industry is one of the prime contributors to the modern economy; its relationship with the gross domestic product of a nation is essential [19]. For South African construction industry the reverse is not the case. However, performance wise, the construction industry has its ups and downs by the nature of the work involved and is known for its competitive nature [20]. Effective leadership therefore is a necessity for optimum performance and high productivity. Hence, it is essential to learn what leadership is, and the vital factors for increasing workers' performance [34]. Proper leadership in any organisation helps mitigate wastage of resources especially time, labour and money while upholding quality of work in general [3]. Unfortunately negligence of leadership has done more harm than good because many professionals solely depended on technical skills to get the job done [25,27]. Technical skills although necessary are still not enough for maximum productivity - we need that extra edge called 
leadership. This is because leadership calls for creativity, calculated risk taking, ability to inspire and influence others, as well as winning with people rather than maintaining standards or just meeting targets $[18,26]$.

On another note, leadership means different things to a lot of people and sometimes is misinterpreted with management [18]. There are many leadership books which have tried to argue and answer the questions of good leadership [9,10,23,32] but there has not been a perfect answer for this question [25]. This is because there are numerous overlaps when relating the differences between leadership and management [14]. However, it was argued that leadership is concerned with the necessary skills and practices required to influence subordinates while management is based on the maintenance of standards [26]. Jarad viewed leadership as a subset of management, indicating that both are essential to facilitate organizational performance $[18,25]$. However it was indicated that real leaders have the capacity to manage but not all managers can lead; hence, leadership is a plus to management [26,32]. Another characteristic of good leaders from literature is the ability to have a clear cut idea and the persistence to see the manifestation of it amid challenges and failures [24]. In addition, leadership calls for the involvement of all the team members to the attainment of the set goals [10,34]. Real leaders primarily focus on what they can contribute rather than what they will get and when this scenario is in place, many things will fall in place [9,10]. In this 21 century, construction professionals need to possess robust leadership skills to effectively lead themselves and their subordinates [18,33]. Finally, with proper leadership, challenges like slowness in adapting to change, unpreparedness to uncertain future, and inappropriate implementation of strategic planning can be mitigated [24,34]. To this effect, this paper investigates the critical leadership factors essential to enhance workers' performance in the South African construction industry.

\section{Leadership defined}

Munroe [29] defined leadership as "the capacity to influence others through inspiration motivated by a passion, generated by a vision, produced by a conviction, ignited by a purpose". Hence, leadership is an act of giving meaningful purpose and direction which in turn causes positive response towards actualising of a desired goal [17]. For Burns [6] leadership is the process of mobilizing resources to trigger desire for accomplishment as well as satisfy the needs and intents of the subordinates. However, it is good to understand that although leadership may start with a position, leadership is not a position, but the capacity to influence others [26]. A leader should have the capacity to envisage a future event; aligns people with that vision and motivates them to actualise the desired goal irrespective of challenges [22]. Fiol et al. [11] further affirmed that leadership is the capacity to motivate people with the aim of contributing to the success and effectiveness of the organisation. This is evident in our everyday life where we see people in positions but does not have the capacity to influence others; thus, fall short of the goal of the organisation. Good leaders empower others to make decisions [15]. Hence, to empower others, there should be a relationship in place [23]. Therefore, leadership can be summed up as an interaction between the people who opt to lead and that react as follower [24,29]. The subordinates choose to follow because, trapped in every follower is a leader [29]. In other words, leadership ability can be developed in every individual [26,27]. Kouzes and Posner [23] also understood this concept, as they defined leadership as a process of bringing forth the best from an individual and others.

\subsection{Essential leadership factors for enhancing workers' performance}

In a complex environment like that of construction where people are required to work together, deal with project pressures and meet targets, leadership challenge therefore becomes unavoidable [24,31,34]. Hence, it is necessary to have strong and exemplary leaders [24]. Although all leaders have a unique signature strength which lets them succeeds in the right context [25], there are essential factors that help enhance performance and effectiveness of an organisation [12,23]. Toor and Ofori [38] noted that leadership disposition includes factors such as personal traits, ability to give clear information and the know-how of situational variables in operation. Hence, leaders are required to build on their strengths; work around areas of weakness for continual improvement [26]. In addition, leadership is a team sport; there is nothing like a lone hero; therefore, a leader is required to work with others who have strengths which will compensate for the gaps [32].

Effective leaders make a difference; they do not accept the status quo [26,29]. They move others and themselves beyond their comfort zones towards actualising the organisational objectives [26]. Effective leaders identify their context; the ability to discover where one can utilise to the best advantage is essential for success [24,38]. An effective leader's aim is to provide support to his/her subordinates or set in place all the necessities for the attainment 
of the set goals [2]. Hence, the essential leadership factors for the enhancement of workers' performance are expounded below.

- Effective communication

Effective communication can help group members to follow through with the given instructions [13]. The key to effective communication is simplicity. Hence, an effective leader distributes information and ideas in a clear and concise manner for easy grasp of what is passed across [7]. In addition, it is important to incorporate emotional intelligence while communicating with subordinates [8].

\section{- Proper Planning}

A strategic leader provides a clear goal, set direction and systematic plans for the attainment of that goal [34]. The value of planning and strategic capability is tremendous if any goal is to be achieved. Proper planning will help people know what to do, when and how to do it. The leader should be able to make use of various types of plan such as strategic plans, contingency plans, tactical and operational plans [4].

\section{- Shared Vision}

Visioning can be defined as a process which is categorised in phases such as the creation stage, improvement stage as well as the renewal stage of the vision [18]. Vision is everything for a leader because it fuels the fire within which helps draw the leader and the subordinates forward [18,36]. Involving people in decision making even when the leader already knows what to do can create a sense of importance and recognition among subordinates [12,24].

- Good dispute management

The ability to limit the negative aspects of conflict in each situation and seek out beneficial ways to cope with the unexpected changes is required in the management of projects [30]. A good project leader ensures that tensions and conflicts are minimised in the organisation.

- Innovative/Initiative

A leader should be on the creative side of events and not on the reactive side [1,18]. Successful leaders keep moving forward and are not complacent; they make things happen and are not afraid of failure [24]. They look out for opportunities and innovative ways to improve and this attitude is a positive influence to the subordinates [24].

- $\quad$ Team building

No man is an island. The bigger the dream the more competent team and collaborative effort required [21]. Hence, good leaders build trust and facilitate relationships to promote collaboration [21]. In addition the leader must ensure that below par performance from any of the team members is addressed on time so that it will not affect the efficiency of the group [27]

- Setting good example

Workers are motivated when the leader clarifies values and procedures as well as align their actions with the shared values [23, 24]. Actions they say, speak better than words. Hence, being a role model and setting good exemplary attitude is likely to create a positive influence on the subordinates' performance and on the organisation [34].

\section{- Supervision}

The leader should make his/her acquired skills to instruct and guide the subordinates to ensuring that they conform to project requirement [30]. He/She may systematically evaluate his subordinates based on their strengths and weakness as this may help reconcile any conflict of interest that may arise among the team members [33]. 
- Inspirational leadership

Leaders utilise their energy towards inspiring people to exercise creativity in solving problems [5]. Zalenik affirmed that the need to maintain order and standards which is driven by management can sometimes stampede the creativity of a leader [39]. He also states that while managers tend to avoid risk, leaders on the other hand, seek them out and act [39].

- Regular meetings

Leadership is acquainted with actions that are principal in mobilizing another action for organisational success such as the presiding of meetings by the leaders [37]. Hence, regular discussions and meetings with workers about their pending targets will ensure that they follow through to their commitments and this will help their accountability [37].

- Contingent rewards

Here the leaders aid in exchange for the effort given and offer recognition for the attainment of the set goals [3]. Good leaders are quick to show appreciation for any outstanding performance from their subordinates and are fair in the rewarding of subordinates [26].

\section{Research methodology}

This research adopted a quantitative approach which involved the use of a questionnaire. Quantitative research is a survey to obtain information from a sample of people by means of self-report from respondents by a sequence of questions posed to them by the researcher [16]. It is one of the cost-effective ways to collect data from many respondents [27]. Hence, 5-point Likert-scale survey questionnaire was constructed from the detailed literature review. Weights were assigned to each response ranging from 1 to 5 from "strongly disagree" to "strongly agree". A purposive sampling was used, targeted at 81 construction professionals in the Gauteng Province of South Africa. $63 \%$ response rate was achieved. The professionals were limited to project managers, architects, quantity surveyors, construction managers, civil engineers and town planners. Data were analysed using the Statistical Package for Social Sciences (SPSS) version 22.0 software. The reliability and internal consistency of the collected data were appraised using Cronbach's alpha $\alpha$. The $\alpha$ value for the leadership factors to enhance workers' performance were 0.81. Mean (M) and standard deviation (SD) values were used as output. Finally the rankings of the critical leadership factors used by the various construction professionals to enhance workers' performance were assessed base on the mean values.

\section{Findings and discussions}

The findings centred on the various leadership factors for performance enhancement from literature. Results according to table 1 revealed that effective communication within the project environment is of the optimum importance having the best ranking of mean (4.50) and standard deviation (0.58). It was followed by proper planning of work for the workforce. $(\mathrm{M}=4.50, \mathrm{SD}=0.61, \mathrm{R}=1)$. Other results and their rankings were as follows: enlisting others in a common vision by appealing to shared aspirations $(\mathrm{M}=4.44, \mathrm{SD}=0.61, \mathrm{R}=3)$; good disputes management skill by the leader $(\mathrm{M}=4.40 ; \mathrm{SD}=0.78 ; \mathrm{R}=4)$; continual search for opportunities and innovative ways to improve $(\mathrm{M}=4.34, \mathrm{SD}=0.67, \mathrm{R}=5)$; creating team building opportunities for employees and facilitating good relationship are essential (MS=4.34, SD, 0.69, $\mathrm{R}=6$ ); setting good example by aligning actions with the shared values has a positive impact of workers' performance $(\mathrm{M}=4.28, \mathrm{SD}=0.73, \mathrm{R}=7)$; adequate guidance and supervision $(\mathrm{MS}=4.18, \mathrm{SD}=0.66$, $\mathrm{R}=8$ ); inspirational leadership is important within a project environment ( $\mathrm{MS}=4.14, \mathrm{SD}=0.97, \mathrm{R}=9$ ); regular discussion and meetings with workers about their pending targets $(\mathrm{MS}=4.12, \mathrm{SD}=0.87, \mathrm{R}=10)$; and contingent rewarding of workers ( $\mathrm{MS}=4.02, \mathrm{SD}=0.82, \mathrm{R}=11$ ). The fact the all the mean of the above statements exceeds the 3.0 out 5.0 scale is a vital proof that all construction professionals agree with these factors from their own experiences in the construction industry.

Findings from this study support the five practices of exemplary leadership for organisational performance enhancement which are: modelling the way, inspiring a shared vision, challenging the process, enabling others to act and encouraging the heart $[12,23]$. Hence, the factors from this study are essential for the leadership challenge of 
improving subordinates and organisational performance especially that of the South African construction industry.

Table 1 Critical leadership factors toward workers' performance in the South African construction industry

\begin{tabular}{llcc}
\hline Critical factors & Mean & Standard deviation & Rank \\
\hline $\begin{array}{l}\text { Effective communication within the project } \\
\text { environment }\end{array}$ & 4.50 & 0.58 & 1 \\
$\begin{array}{l}\text { Proper planning of work for the workforce } \\
\begin{array}{l}\text { Enlisting others in a common vision by } \\
\text { appealing to shared aspirations }\end{array}\end{array}$ & 4.50 & 0.61 & 1 \\
$\begin{array}{l}\text { Good disputes management skills by the } \\
\text { leadership }\end{array}$ & 4.44 & 0.61 & 3 \\
$\begin{array}{l}\text { Continual search for opportunities and } \\
\text { innovative ways to improve performance }\end{array}$ & 4.38 & 0.78 & 4 \\
$\begin{array}{l}\text { Creating team building opportunities for } \\
\text { employees and facilitating good relationship }\end{array}$ & 4.34 & 0.67 & 5 \\
$\begin{array}{l}\text { Setting good example by aligning actions with } \\
\text { shared values }\end{array}$ & 4.28 & 0.69 & 6 \\
$\begin{array}{l}\text { Adequate supervision and guidance } \\
\text { Inspirational leadership }\end{array}$ & 4.18 & 0.73 & 7 \\
$\begin{array}{l}\text { Regular discussions and meetings } \\
\text { Contingent rewarding of workers }\end{array}$ & 4.14 & 0.66 & 8 \\
\hline
\end{tabular}

\section{Conclusions}

The study set out to establish the essential leadership factors for workers' performance enhancement in the South African construction industry. Leadership was defined and its importance for organisational success was also emphasised. Findings revealed that effective communication within the project environment and proper planning of work for the workforce are of the optimum importance for performance enhancement and effectiveness. It also revealed that the enlistment of subordinates in a common vision by appealing to shared aspirations contributes to optimum performance. It further revealed that good dispute management, continual search for innovative ways of improvement, setting exemplary actions by the leader, proper supervision of work, regular meeting with subordinates, and contingent rewards for job well done are all essential for organisational effectiveness and performance enhancement. The study provides useful insight to develop measures to improve construction workers' performance which will in turn mitigate project delays, and decrease cost overruns. Hence, appropriate implementation of these factors will do more good than harm to the overall productivity of the South African construction industry.

\section{References}

[1] Adair, J. (2005). Leadership for innovation: How to organize team creativity and harvest ideas. Philadelphia: Kopan Page Limited.

[2] Adogbo, K.J., Kolo, B.A. and Nzekwe, K.C.L. (2017). Assessment of organisational leadership for knowledge management practice in the Nigeria construction industry. Journal of Construction Project Management and Innovation, 7 (1):1997-1994.

[3] Bass, M. and Avolio, J. (2004). Improving organisational effectiveness through transformational leadership. California: Thousand Oaks.

[4] Bedi, K. (2009). Management and entrepreneurship. Oxford press. New Delhi.

[5] Bennis, W. and Nanus, B. (2007). Leaders: Strategies for Taking Charge. Collins business. Canada: Harper Business.

[6] Burns, J.M. (1978). Leadership. NY.

[7] Bushman, M. (2007). The responsibility of a project manager. Associated Content Inc, available at: www.associatedcontent.com/article/131998/ the_responsibilities_of_aproject_manager.htm (accessed 24 February 2018).

[8] Clarke, N.(2010). The impact of a training programme designed to target the emotional intelligence abilities of project managers, Intenational Journal of Project Management, 28(5):461-468.

[9] Daft, R.L. (2003). Management. 6th edition. Thompson South-Western: OH.

[10] DuBrin A, J. (2010). Principles of Leadership. 6th edition. Rochester: Cengage Learning.

[11] Fiol, C.M., Harris, D. and House, R., 1999. Charismatic leadership: Strategies for effecting social change. The Leadership Quarterly, 10(3):449-482.

[12] Fullan M. (2011). The six secrets of change: What the best leaders do to help their organisations survive and thrive. John Wiley \& Sons. 
[13] Goetsh, D.L. (2004). Effective teamwork: ten steps for technical professions. New Jersey: Prentice Hall.

[14] Gridham, T. (2006). November. Coss-cultural leadership in construction. In Proceedings of the International Conference on ConstructionCulture, Innovation, and Management, Dubai, UAE (PP.26-29).

[15] Havenga, R. (2002). The new leadership challenge: Teaming principles with practices in times of change, Management Today, 9(3):225 247.

[16] Hungler, B.P. and Polit, D.F. (1993). Nursing research: Principles and methods. 3rd edition. Philadelphia: Lippincott.

[17] Jacobs, T.O. and Jaques, E. (1990). Military executive leadership.

[18] Jarad, G.H. (2012). The construction manager leading characteristics for the success of construction projects in the Gaza Strip. Master's Thesis, The Islamic university of Gaza.

[19] Jekale, W. (2004). Performance of public construction projects in developing countries: Federal road and educational building projects in Ethiopia. Norwegian University of Science \& Technology.

[20] Kashiwagi, D.T and Byfield, R. (2002). Best Value Procurement. Tempe. AZ, Netherland: Performance Studies Research Group.

[21] Kerzner, H. (1992). Project Management - A System Approach to Planning, Scheduling and Controlling,.Van Nostrand Reinhold, New York, NY.

[22] Kotter, J.P. (1988). The Leadership Factor. New York: The Free Press.

[23] Kouzes, J.M. \& Posner, B. Z. (1996). The Leadership Challenge: How to keep getting Extraordinary Things Done in Organisation.San Francisco: Jossey - Bass.

[24] Kouzes, J.M. and Posner, B.Z., (2006). The leadership challenge (Vol.3). John Wiley \& Sons.

[25] Liphadzi, M. (2015).Leadership style practices by Construction Managers and Project Managers in the South African Construction Industry. Johannesburg: University of Johannesburg. Available from: https://ujdigispace.uj.ac.za (Accessed on 20 February 2018).

[26] Maxwell, J.C. (2007). The 21 indispensable qualities of a leader: Becoming the person others will want to follow. Thomas Nelson.

[27] McCuen, R.H., Ezzell, E.Z. and Wong, M.L. (2011). Fundamentals of Civil Engineering: An introduction to the ASCE Body of Knowledge. CRC Press.

[28] McQueen, R.A. and Knussen, C. (2002). Research Methods for Social Science: A Practical Introduction. Harlow: Prentice Hall.

[29] Munroe, M. (2005). Spirit of Leadership. Whitaker House.

[30] Obiajunwa, C.C. (2013). Skills for the management of turnaround maintenance projects. Journal of Quality in Maintenance Engineering, 19(1):61-73.

[31] Ogunlana, S. (2008). Performance and leadership outcome correlates of leadership styles and subordinate commitment. Engineering Construction and Architectural Management, 15 (2):7-99.

[32] Owen, J. (2012).The Leadership skills Handbook: 50 Essential skills you need to be a leader. 2nd Edition. UK: British Library Publication.

[33] Pheng, L.S., Keong, B.L.S. (1999). Developing construction project management skills: lessons from Zhuge Liang's Art of Management. Career Development International, 4(1):34-39.

[34] Price, J. (2009).The Conception and Operationalization of leadership in construction companies, Master's Degree Thesis. Pretoria: UNISA.

[35] Riggio, R.E. and Reichard, R.J. (2008). The emotional and social intelligences of effective leadership. An emotional and social skill approach. Journal of managerial psychology, 23 (2): 169-185.

[36] Shelbourn, M., Hassan, T. \& Carter. C.H. (2003). Vision for the integration of contractual and legal aspects of ICT into networked cooperation in construction. UK: Loughborough University.

[37] Svennevig, J. (2011). Leadership style in managers' feedback in meetings. In Constructing identities at work(pp.7-39). Palgrave Macmillan, London.

[38] Toor, S.U.R. and Ofori, G. (2008). Leadership versus management: How they are different, and why. Leadership and Management in Engineering.

[39] Zaleznik, A. (2004). Managers and Leaders: Are they different? Hav Bus Rev, 82(1):74-81. 